\title{
Article \\ A Scientometric Analysis of Forty-Three Years of Research in Social Support in Education (1977-2020)
}

\author{
Shaista Rashid ${ }^{1}$, Shafiq Ur Rehman ${ }^{2, *}\left(\mathbb{D}\right.$, Murtaza Ashiq ${ }^{3,4}\left(\mathbb{D}\right.$ and Amira Khattak ${ }^{5}(\mathbb{D}$ \\ 1 Department of English, College of Humanities, Prince Sultan University, Riyadh 11586, Saudi Arabia; \\ srashid@psu.edu.sa \\ 2 Deanship of Library Affairs, Imam Abdulrahman Bin Faisal University, Dammam 31441, Saudi Arabia \\ 3 Library and Information Science, Islamabad Model College for Boys, H-9, Islamabad 44000, Pakistan; \\ gmurtazaashiq00@gmail.com \\ 4 Institute of Information Management, University of the Punjab, Lahore 54590, Pakistan \\ 5 Department of Marketing, College of Business Administration, Prince Sultan University, \\ Riyadh 11586, Saudi Arabia; akhattak@psu.edu.sa \\ * Correspondence: suRehman@iau.edu.sa
}

check for updates

Citation: Rashid, S.; Rehman, S.U.; Ashiq, M.; Khattak, A. A

Scientometric Analysis of Forty-Three Years of Research in Social Support in Education (1977-2020). Educ. Sci. 2021, 11, 149. https://doi.org/ 10.3390/educsci11040149

Academic Editor: Gavin T. L. Brown

Received: 21 February 2021

Accepted: 23 March 2021

Published: 26 March 2021

Publisher's Note: MDPI stays neutral with regard to jurisdictional claims in published maps and institutional affiliations.

Copyright: (c) 2021 by the authors. Licensee MDPI, Basel, Switzerland. This article is an open access article distributed under the terms and conditions of the Creative Commons Attribution (CC BY) license (https:// creativecommons.org/licenses/by/ $4.0 /)$.

\begin{abstract}
This scientometric study examines the overall research trends, publication and citation structures, authorship and collaboration patterns, bibliographic coupling, and productivity patterns in the field of social support in education. Bibliometric data consisting of 545 documents was retrieved from the Scopus database during a period of 43 years (1977-2020) on 1 January 2021. Data analysis was performed using various scientometric software including MS Excel, VOS Viewer, Biblioshiny, CiteSpace and ScientoPy. The results of the study revealed that the first publication on this topic appeared in 1977, however, the major increase was observed during 2017-2020, whereas the maximum number of publications $(N=57)$ in a single year was published in the year 2020. Similarly, the highest number of citations $(n=1002)$ were observed in the year 1995 with an average of 334 citations per document. The most productive countries were the United States $(N=194)$, the United Kingdom $(\mathrm{N}=56)$, and Australia ( $\mathrm{N}=50$ publications). Results further indicated that more than $50.7 \%$ of the research in the social support area was done in medicine. Overall, the findings of the study reveal that most of the research in the aforementioned field originated from the developed countries which can be related to the developments in the medical field. The study indicates the importance of social support in the educational context due to an increased trend of inclusion and diversity in the education field. This research is the first bibliometric study in the field of social support in education.
\end{abstract}

Keywords: social support-education; social support-bibliometric; well-being; informational supporteducation; bibliographic coupling

\section{Introduction}

Social support is often a common study area in social-psychological and socialeducational research focusing on social relationships within the members of the same community. It is achieved through interpersonal and inter group relationships [1] and is referred to as a mutual interaction between people, which can be affected by individual character, the nature of the relationship and socio-economical differences [2]. Social support is defined as "an individual's perceptions of general support or specific supportive behaviors (enabled or enacted upon) from people in their social network, which enhances their functioning and/or may buffer them from adverse outcomes" [3].

Social support comprises both qualitative as well as quantitative aspects under its umbrella [4]. Elaborating on the qualitative aspect, it is more of a process and usually points to the supposed values and expressions received in a social relationship. Adams hypothesized that the three major factors of any social network were a sense of duty or 
responsibility, feelings of affection and some common grounds such as interests, shared values etc. [5]. Moreover, Cobb identified three components of social support. Firstly, one's admittance that they are cared for and loved (succor, nurturance, and affiliation), secondly that they are acknowledged (recognition and respect), and lastly that they are a part of a network and have certain duties (group membership) [6]. Hence, social support was classified into four main categories by many researchers [1,7-9]. These are "informational support", in the form of advice, suggestion etc. [9]; "tangible support", in the form of financial or material assistance [10]; "emotional support", described as showing concern, love, empathy, etc. [11] usually provided by family and close friends and "social integration support", perceived as promoting a sense of belonging [9]. Social integration is more oriented towards kinship and relationships rather than social action and interactions [1]

Social support plays a crucial role in ensuring students' well-being in an educational context [12-14] It can be defined as the overall "perception one has of being cared for, valued, and included by others within a network of caregivers, teachers, peers, and community members [15]. Due to different stages of one's educational journey, students are often faced with change and transition, which is referred to as a setting stone period in the lives of students $[16,17]$. This change is not confined to just change in academic course books and physical location of the classroom, it extends to adaptation to new places, people, routines [16], culture, language, social customs, etc. The impact of these changes and transitions can range from physical health to psychological and emotional well-being [18]. Furthermore, this period of change and transition can be different for different students, demanding different amounts of time and effort and can further influence their performances negatively or positively [19]. The adaptation to new places, people and lifestyles may lead to change students' overall cultural behaviors as they are likely to lose control of the new environment because of their previous experiences. In this scenario, social support can prove influential as it can help students to cope with the new challenges and reduce stress. This support can be offered by classmates, parents and teachers.

The importance of the role played by the family members, teachers and peers in students' happiness, academic achievement, motivation, cooperation, and school adjustment has been emphasized by many researchers $[14,18,20,21]$. Furthermore, teachers are considered to provide both instructional as well as emotional support to students in the educational context, though parents are commonly considered emotional support providers to children and young adults [22,23]. This instructional and emotional support further expands to help students from being dropped out [24]. Studies have shown that preferences for social support providers (for example, teachers, peers, family members/caregivers) change with the passage of time. For example, children in elementary schools prefer their family members/caregivers [25], middle school students prefer both their friends and caregivers [26] and by age sixteen, they rely on their peers and friends for social support [27]. On the other hand, younger students receive more social support from teachers as compared to older students [27]. Furthermore, students' individual differences in socioeconomic status [28], gender [29], culture [30], and race and ethnicity [31] also affects the influence of social support on students.

There are a plethora of research studies in the field of social support in the educational context. However, the research contexts are not limited to teaching and learning in an educational setting, rather it expands to health education [32], family education [33-35], community education [36] and work-related professional settings [37]. It is interesting to note that until now no bibliometric study has been published to examine and document research trends in the role played by social support in the lives of students and teachers in an educational setting. As bibliometric studies offer insights into quantitative aspects [38] of research trends in a particular field, such a study in the above-mentioned field will not only shed light on existing research trends in exploring the role of social support in educational setting but will also help researchers to identify future research areas and help policy makers in making effective policy decisions [39]. Hence, this study aims to explore the following research questions. 
1. What are the publishing and citation structure in social support research in education from 1977 to 2020 ?

2. Which of the countries, organizations, and authors are most productive in social support in education research?

3. Which journals are frequently preferred by social support researchers?

4. What are the authorship and collaborative patterns of researchers working on social support in education?

5. What are most frequent keywords and major themes used in social support research in education?

6. What kind of bibliographic coupling of countries, journals and authors exist in the social support research in education?

\section{Methodology}

\subsection{Method}

The bibliometric method was used to examine the publications output, research trends and publishing patterns on social support in education. Bibliometric is a quantitative method for analyzing publishing trends of scholarly documents (research articles, conference papers and books etc.) Tijjani et al. described bibliometric method as "an established quantitative method to investigate publishing patterns of scholarly work" [40]. Further, it is a method that provides scientific landscape of authors, countries, organizations, and collaborations contributing in global scientific literature [41]. Bibliometric data from published literature on social support were extracted. Conceptual (co-occurrences of authors/keywords, thematic evolution), intellectual (co-citation network), and social (collaboration network) structures of the retrieved data were also studied.

\subsection{Database Selection}

There are many indexing and citation databases, with global and regional coverage of journals, books, reviews, and conference proceedings. Each database has its style, concentration, and area of focus. Scopus was selected to extract the data because of its comprehensive coverage in the field of social sciences. Scopus is the world's largest data source of peer reviewed scientific literature with 75 million indexed items. Furthermore, Scopus updates the data on daily basis and 32\% of the overall content indexed in Scopus belongs to the social sciences literature. Furthermore, there are number of studies that prioritize Scopus (over other databases such as Web of Science, Dimensions, etc.) for bibliometric studies due to its largest data source [42,43]. Scopus is also known as a curated, and high-quality bibliometric data source for academic research. Researchers have been using it as a bibliometric data source on a large-scale [42-44].

\subsection{Search Query}

To retrieve the bibliographic data on social support in education, the following search query was run in the main search interface of the Scopus database in the search field type: "Article Title, Abstract, Keywords." Search terms were combined by the operator "AND" TITLE-ABS-KEY ("social support" AND education) AND SUBJAREA (soci).

\subsection{Date of Data Extraction}

The query was run on the 1st of January 2021 at Imam Abdulrehman Bin Faisal University, Saudi Arabia. A total of 4464 documents were found using this search query.

\subsection{Inclusion/Exclusion Criteria}

No publication year filter was used to get these 4464 documents; however, search results were limited to Scopus sub-categories related to social sciences. The search was also limited to article, book, book chapter, conference paper, and review articles. No language or geographical filters were applied. Short survey, note, editorial, letter, conference review, retracted, and undefined document types were excluded. From the initial search results 
of 4464 documents, 3813 records were excluded after individual screening of titles and abstracts of all acceptable documents. The final 545 records consisting of articles $(\mathrm{N}=490)$, Books $(\mathrm{N}=6)$, book chapters $(\mathrm{N}=16)$, conference papers $(\mathrm{N}=2)$, and review articles $(\mathrm{N}=31)$ appeared in the period from 1977 to 2020 (Figure 1).
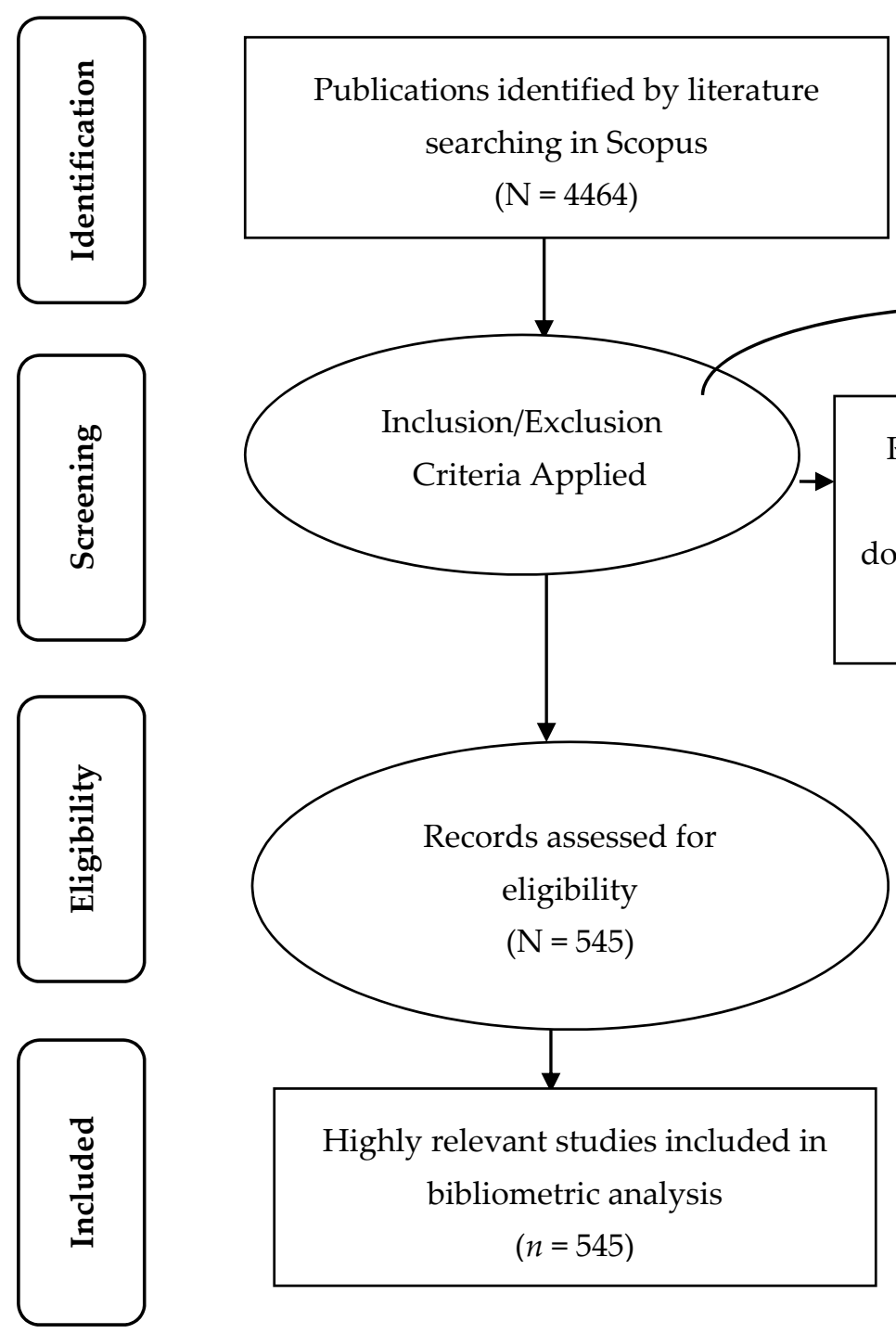

Figure 1. Four-phase flow diagram of data extraction and filtration process of social support in education.

The whole process was repeated by two authors to standardize the selection of items and ensure the data's accuracy.

\subsection{Data Analysis}

Different bibliometric analysis tools were used to get meaningful data from the 545 yielded documents. MS Excel (V16.0) was used to perform some basic functions, e.g., to know publications and citation trends. VOS viewer (version 1.6.15), Biblioshiny (version 2.0), CiteSpace (version 5.7.R3), Gephi (version 0.9.2), and ScientoPy (version 2.0.3.) are the tools that helped the authors in data visualization such as journals, researchers, and individual publications. The tools were also used in finding the relations in citations, bibliographic coupling, co-citation, or co-authorship. 


\section{Results and Discussion}

\subsection{Research Productivity}

Figure 2 depicts the annual research productivity in social support in education in terms of publications and citations. The first publication on this topic appeared in 1977 and was unable to get any citation. After the appearance of the first publication in 1977, social support in education research productivity progressively increased. The major increase was observed during 2017-2020, where 38\% of the publications were produced. In 1995, three publications were cited 1002 times. The maximum number of publications $(\mathrm{N}=57)$ occurred in year 2020.

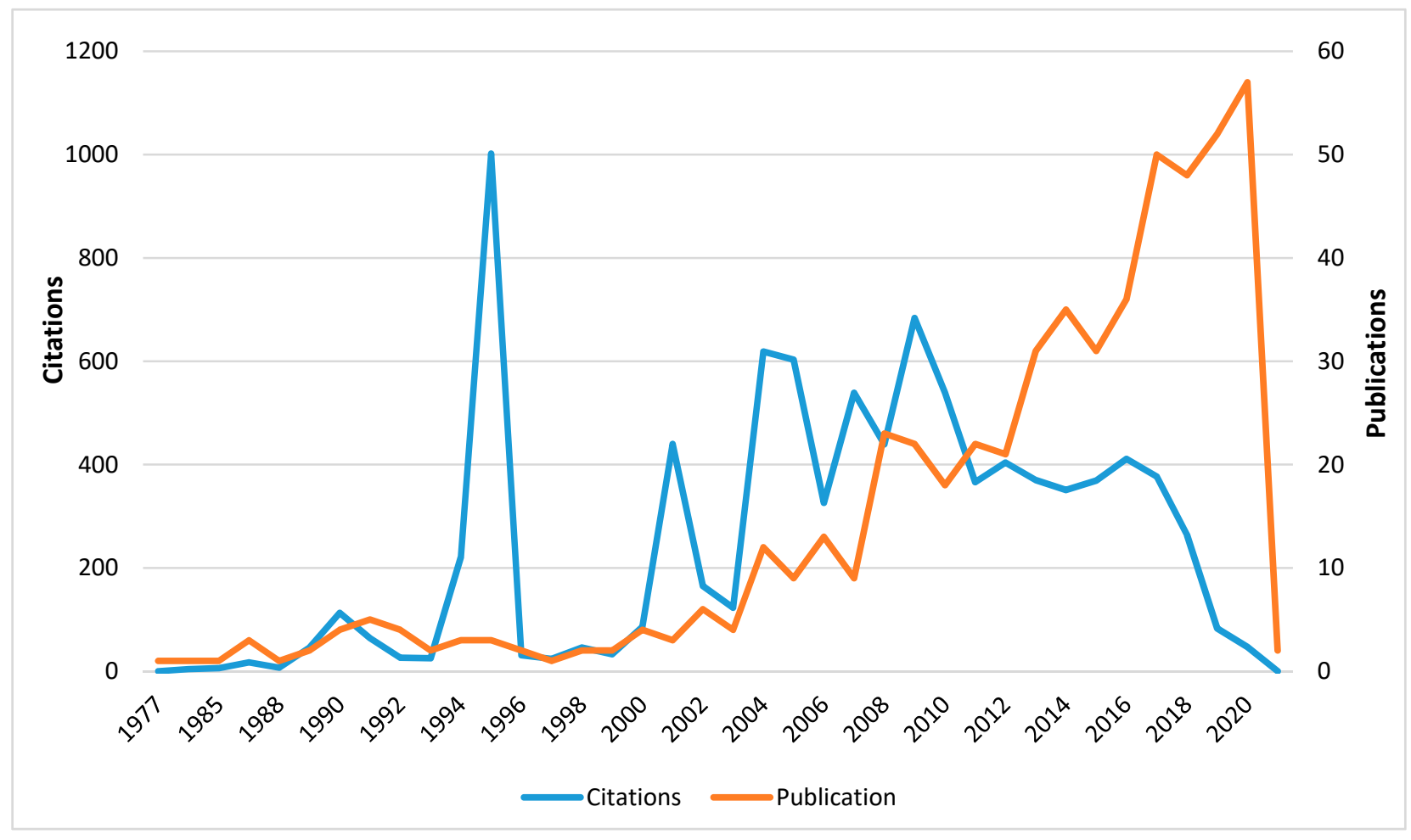

Figure 2. Publications and citation trends in social support in education from 1977 to 2020.

\subsection{Publishing and Citation Structure of Social Support in Education}

Table 1 demonstrates annual publishing and citation structure of social support in education. A total of 383 publications ( $70.28 \%$ of total publications) were produced between 2011-2020, and the number of citations during the same time period was 3042 (32.82\% of total received citations). The highest number of documents $(N=57)$ appeared in 2020 while the highest number of citations $(N=1002)$ were received in the year 1995 with an average of 334 citations per document. The publication trends indicate that the research on social support in education is significantly increasing with the passage of time. The average citations per cited publication (C/CP) of 1995 is 334 . The year 2001 has $146.67 \mathrm{C} / \mathrm{P}$ and C/CP, followed by 1994 (73.67 C/P and C/CP). 
Table 1. Citation structure of social support in education publications between 1977 and 2020 .

\begin{tabular}{|c|c|c|c|c|c|c|}
\hline PY & TP & $\mathrm{TC}$ & NCP & $\mathrm{C} / \mathrm{P}$ & $\mathrm{C} / \mathrm{CP}$ & H-Index \\
\hline 1977 & 1 & 0 & 0 & 0.00 & 0 & 0 \\
\hline 1983 & 1 & 4 & 1 & 4.00 & 4.00 & 1 \\
\hline 1985 & 1 & 6 & 1 & 6.00 & 6.00 & 1 \\
\hline 1987 & 3 & 17 & 2 & 5.67 & 8.50 & 2 \\
\hline 1988 & 1 & 7 & 1 & 7.00 & 7.00 & 1 \\
\hline 1989 & 2 & 46 & 2 & 23.00 & 23.00 & 2 \\
\hline 1990 & 4 & 113 & 4 & 28.25 & 28.25 & 4 \\
\hline 1991 & 5 & 64 & 4 & 12.80 & 16.00 & 4 \\
\hline 1992 & 4 & 26 & 4 & 6.50 & 6.50 & 3 \\
\hline 1993 & 2 & 25 & 2 & 12.50 & 12.50 & 2 \\
\hline 1994 & 3 & 221 & 3 & 73.67 & 73.67 & 3 \\
\hline 1995 & 3 & 1002 & 3 & 334.00 & 334.00 & 2 \\
\hline 1996 & 2 & 31 & 2 & 15.50 & 15.50 & 2 \\
\hline 1997 & 1 & 24 & 1 & 24.00 & 24.00 & 1 \\
\hline 1998 & 2 & 46 & 2 & 23.00 & 23.00 & 2 \\
\hline 1999 & 2 & 33 & 2 & 16.50 & 16.50 & 2 \\
\hline 2000 & 4 & 86 & 3 & 21.50 & 28.67 & 2 \\
\hline 2001 & 3 & 440 & 3 & 146.67 & 146.67 & 3 \\
\hline 2002 & 6 & 165 & 6 & 27.50 & 27.50 & 6 \\
\hline 2003 & 4 & 123 & 4 & 30.75 & 30.75 & 4 \\
\hline 2004 & 12 & 619 & 11 & 51.58 & 56.27 & 11 \\
\hline 2005 & 9 & 603 & 9 & 67.00 & 67.00 & 8 \\
\hline 2006 & 13 & 326 & 13 & 25.08 & 25.08 & 9 \\
\hline 2007 & 9 & 539 & 8 & 59.89 & 67.38 & 8 \\
\hline 2008 & 23 & 439 & 20 & 19.09 & 21.95 & 12 \\
\hline 2009 & 22 & 684 & 21 & 31.09 & 32.57 & 12 \\
\hline 2010 & 18 & 539 & 17 & 29.94 & 31.71 & 13 \\
\hline 2011 & 22 & 366 & 19 & 16.64 & 19.26 & 9 \\
\hline 2012 & 21 & 404 & 21 & 19.24 & 19.24 & 10 \\
\hline 2013 & 31 & 370 & 27 & 11.94 & 13.70 & 14 \\
\hline 2014 & 35 & 351 & 31 & 10.03 & 11.32 & 11 \\
\hline 2015 & 31 & 369 & 29 & 11.90 & 12.72 & 12 \\
\hline 2016 & 36 & 411 & 30 & 11.42 & 13.70 & 10 \\
\hline 2017 & 50 & 377 & 40 & 7.54 & 9.43 & 12 \\
\hline 2018 & 48 & 264 & 40 & 5.50 & 6.60 & 8 \\
\hline 2019 & 52 & 83 & 29 & 1.60 & 2.86 & 4 \\
\hline 2020 & 57 & 47 & 12 & 0.82 & 3.92 & 5 \\
\hline 2021 & 2 & 0 & 0 & 0.00 & 0.00 & 0 \\
\hline
\end{tabular}

These findings indicate that the discipline has progressed slowly but has gained prominence in 2020 in terms of publication. Until now research in the social support area was limited to health education [32], family education [33-35], community education [36] and work-related professional setting [37]. One of the main reasons of increased research in the social support in education could be the increased diversity in university enrollments in terms of age, gender and nationalities discussed in-depth in the proceeding sections. Another reason for this increase could be the revolution and ubiquity of information technology (IT) in education and social support.

Table 1 shows "social support in education" annual citation structure between 1977 and 2020. It also shows the total number of social support in education publications (TP), number of cited publications (NCP), total citations (TC), average citations per publication $(\mathrm{C} / \mathrm{P})$, average citations per cited publication $(\mathrm{C} / \mathrm{CP})$, and the h-index $(\mathrm{h})$.

\subsection{Leading Countries and Institutions}

Table 2 summarizes the top ten countries and organizations on social support in education research productivity in terms of publications, citations, and citation impact. The top countries with the highest number of publications included the United States 
( $\mathrm{N}=194)$, the United Kingdom ( $\mathrm{N}=56 \mathrm{~s}$ ), and Australia ( $n=50$ publications). Israel, at the bottom of the list, produced 9 publications. Publications from the United States were cited 3392 times and had a citation impact of 17.48. Despite lower publication volumes, publications originating in Canada $(\mathrm{N}=31)$ had higher citation impact (30.87). Spain had the lowest citation impact (2.67) with 15 publications and 40 citations among the top ten countries.

Table 2. Leading countries and institutions.

\begin{tabular}{|c|c|c|c|c|c|c|c|c|c|}
\hline \multicolumn{5}{|c|}{ Top 10 Countries } & \multicolumn{5}{|c|}{ Top 10 Organizations } \\
\hline Rank & Country & TP & TC & CI & Rank & Organization & TP & TC & CI \\
\hline 1 & United States & 194 & 3392 & 17.48 & 1 & $\begin{array}{c}\text { The University of Texas } \\
\text { at Austin }\end{array}$ & 10 & 230 & 23.00 \\
\hline 2 & United Kingdom & 56 & 1377 & 24.59 & 2 & Maastricht University & 7 & 57 & 8.14 \\
\hline 3 & Australia & 50 & 581 & 11.62 & 3 & $\begin{array}{c}\text { University of Illinois } \\
\text { at Chicago }\end{array}$ & 7 & 116 & 16.57 \\
\hline 4 & Canada & 31 & 957 & 30.87 & 4 & University of Florida & 6 & 48 & 8.00 \\
\hline 5 & Germany & 25 & 303 & 12.12 & 5 & $\begin{array}{c}\text { Humboldt University } \\
\text { of Berlin }\end{array}$ & 5 & 123 & 24.60 \\
\hline 6 & Turkey & 21 & 86 & 4.10 & 6 & University of Helsinki & 5 & 74 & 14.80 \\
\hline 7 & Netherlands & 17 & 292 & 17.18 & 7 & University of Antwerp & 5 & 121 & 24.20 \\
\hline 8 & Spain & 15 & 40 & 2.67 & 8 & $\begin{array}{c}\text { The Education University } \\
\text { of Hong Kong }\end{array}$ & 5 & 21 & 4.20 \\
\hline 9 & South Africa & 13 & 42 & 3.23 & 9 & $\begin{array}{l}\text { University of New South } \\
\text { Wales, Sydney, Australia }\end{array}$ & 5 & 101 & 20.20 \\
\hline 10 & Israel & 9 & 124 & 13.78 & 10 & Florida State University & 5 & 24 & 4.80 \\
\hline
\end{tabular}

As far as the top 10 organizations in social support in education are concerned, the University of Texas is at the top with 10 publications and 230 citations. Maastricht University and the University of Illinois at Chicago both are at number two with 7 publications each and 57 and 116 citations, respectively followed by the University of Florida (6 publications and 48 citations). The remaining six organizations contributed 5 publications each. Five publications from the Humboldt University of Berlin got 123 citations and had a citation impact of 24.6. The University of Antwerp with the same number of publications as that of the Humboldt University of Berlin was able to get 121 citations and had a citation impact of 24.2. The top organization in terms of publications, the University of Texas at Austin, received 230 citations and is at number three with a citation impact of 23 . The citation impact of the Education University of Hong Kong is 4.2 (5 publications and 21 citations).

There may be various reasons behind the highest contributions by the institutions from developed countries. For instance, there is an increase in the enrollment of international students in the universities in OECD (developed) countries. These enrollments are not only diverse from age perspectives but from nationality perspectives as well. As mentioned by Mishra, during the last ten years the enrolment of students aged 25 to 34 years in the universities of Australia, Czech Republic, Greece, Iceland, Italy, Netherlands, and Switzerland has increased by more than $10 \%$ [45]. Furthermore, there is an increase in international students by $85 \%$ in the United States only [46]. As stated by Vedder et al., all students irrespective of their cultural background require social support and in particular immigrant (international) students [14]. Hence the increasing number of students in universities in terms of diversity necessitate a social support system in the education sector and related research.

\subsection{Most Productive Authors}

Table 3 lists the most productive authors for social support in education research. The author, Pyhältö, K. affiliated with the University of Oulu had 5 publications, and was cited 74 times with a citation impact of 14.80 (the most in the list). Seven authors (Soini, T., Gijbels, D. Bodycott, P., Mak, A.S., Ramos-Díaz, E. and Yu, B.) produced 21 publications with an 
equal share and received 53, 53, 43, 23, 23, 17, and 7 citations, respectively. Cunningham, $\mathrm{M}$. is on the bottom of the list but with a high number of citations (45) and high citation impact (22.5). The overall productive authors result indicates that this is an emerging area and have scope for significant researchers in the future.

Table 3. The Top 10 most influential authors in the field of social support in education between 1977 and 2020.

\begin{tabular}{|c|c|c|c|c|c|c|c|}
\hline Rank & Authors & Affiliation & Country & $\mathbf{T P}$ & TC & CPY & h-Index \\
\hline 1 & Pyhältö, K. & University of Oulu & Finland & 5 & 74 & 14.80 & 5 \\
\hline 2 & Ramos-Díaz, E. & $\begin{array}{l}\text { The University of the } \\
\text { Basque Country }\end{array}$ & Spain & 3 & 17 & 5.67 & 3 \\
\hline 3 & Soini, T. & University of Tampere & Finland & 3 & 53 & 17.67 & 3 \\
\hline 4 & Pietarinen, J. & University of Eastern Finland & Finland & 3 & 53 & 17.67 & 3 \\
\hline 5 & Bodycott, P. & University of Canberraact & Australia & 3 & 23 & 7.67 & 2 \\
\hline 6 & Gijbels, D. & University of Antwerp & Belgium & 3 & 43 & 14.33 & 2 \\
\hline 7 & Mak, A.S. & University of Canberraact & Australia & 3 & 23 & 7.67 & 2 \\
\hline 8 & Yu, B. & $\begin{array}{c}\text { The Education University of } \\
\text { Hong Kong }\end{array}$ & Hong Kong & 3 & 7 & 2.33 & 1 \\
\hline 9 & Cunningham, $\mathrm{M}$. & Tulane University, New Orleans & United States & 2 & 45 & 22.50 & 2 \\
\hline 10 & Jaarsma, A.D.C. & $\begin{array}{l}\text { University Medical } \\
\text { Center Groningen }\end{array}$ & Netherlands & 2 & 21 & 10.50 & 2 \\
\hline
\end{tabular}

This table lists the top authors on social support in education with at least two publications and seven citations between 1977 and 2020. It also shows the institution and country affiliated with the author, total number of publications by each author (TP), total citations associated with these publications (TC), citations per publication $(\mathrm{C} / \mathrm{P})$, and h-index (h).

\subsection{Most Influential Journals}

Table 4 presents the top 10 research journals that produced literature on social support in education. These ten journals produced 165 publications (36\%); four of those journals produced over 100 publications. Academic Medicine (Quartile 1), BMC Medical Education (Quartile 2), and Medical Teacher (Quartile 1) emerged as top sources with a total of 90 publications and 2463 citations, followed by the Medical Education (Quartile 1) with 29 publications and 1228 citations. Three journals, Social Work Education, Medical Education Online and Teaching and Learning in Medicine produced 21 publications with an equal share and received a total of 346 citations; these three journals are in Quartile 2. Social Work Education is the only nonimpact factor journal in this list. As found in the present bibliometric study, more than $50.7 \%$ of the research in the social support area has been done in medicine and the supremacy of this area might be related to its evolution and relevance [47]. Academic Medicine was the source with the highest impact factor (5.354); it produced 30 publications and received the highest number of citations (1235). Most of the journals belonged to England (5) and the United States (3), while Netherlands and Sweden had one journal each. This shows that the research of this area has better chances to get published in the impact factor journals. 
Table 4. Most influential journals on social support in education.

\begin{tabular}{|c|c|c|c|c|c|c|c|}
\hline Rank & Journal & TP & TC & IF & $Q$ & Publisher & Country \\
\hline 1 & Academic Medicine & 30 & 1235 & 5.354 & 1 & $\begin{array}{l}\text { Lippincott Williams \& } \\
\text { Wilkins }\end{array}$ & United States \\
\hline 2 & BMC Medical Education & 30 & 565 & 1.831 & 2 & Biomed Central Ltd. & England \\
\hline 3 & Medical Teacher & 30 & 663 & 2.654 & 1 & Taylor \& Francis Ltd. & England \\
\hline 4 & Medical Education & 29 & 1228 & 4.57 & 1 & $\begin{array}{l}\text { Wiley-Blackwell } \\
\text { Publishing Ltd. }\end{array}$ & England \\
\hline 5 & $\begin{array}{l}\text { Journal of Studies in } \\
\text { International Education }\end{array}$ & 9 & 171 & 2.148 & 2 & Sage Publications Inc & United States \\
\hline 6 & $\begin{array}{l}\text { Studies in Higher } \\
\text { Education }\end{array}$ & 8 & 513 & 3 & 1 & $\begin{array}{l}\text { Routledge Journals, } \\
\text { Taylor \& Francis Ltd. }\end{array}$ & England \\
\hline 7 & $\begin{array}{l}\text { Advances in Health } \\
\text { Sciences Education }\end{array}$ & 8 & 125 & 2.48 & 1 & Springer & Netherlands \\
\hline 8 & Social Work Education & 7 & 136 & N.A & 2 & Taylor and Francis Ltd. & England \\
\hline 9 & $\begin{array}{l}\text { Medical Education } \\
\text { Online }\end{array}$ & 7 & 92 & 1.97 & 2 & Co-Action Publishing & Sweden \\
\hline 10 & $\begin{array}{l}\text { Teaching and Learning } \\
\text { in Medicine }\end{array}$ & 7 & 118 & 1.848 & 2 & Taylor \& Francis Ltd. & United States \\
\hline
\end{tabular}

\subsection{Authorship Pattern}

Figure 3 depicts the authorship patterns in social support in education. The top three authorship patterns were two authors (134 publications), three authors (125 publications), and one author (124 publications). This pattern trend is quite opposite to other disciplines where top authorship patterns comprise more than 3 authors [48]. This trend may be attributed to the slow progress of the field and a limited number of research publications, mainly from a limited number of countries (developed). The relationship between authors and publications is inversely proportional from four authors to nine authors; an increase in the number of authors resulted in a decrease in the number of publications. No publication is authored by ten or twelve authors. 11,13 and 14 authors have the same number of publications, that is, one.

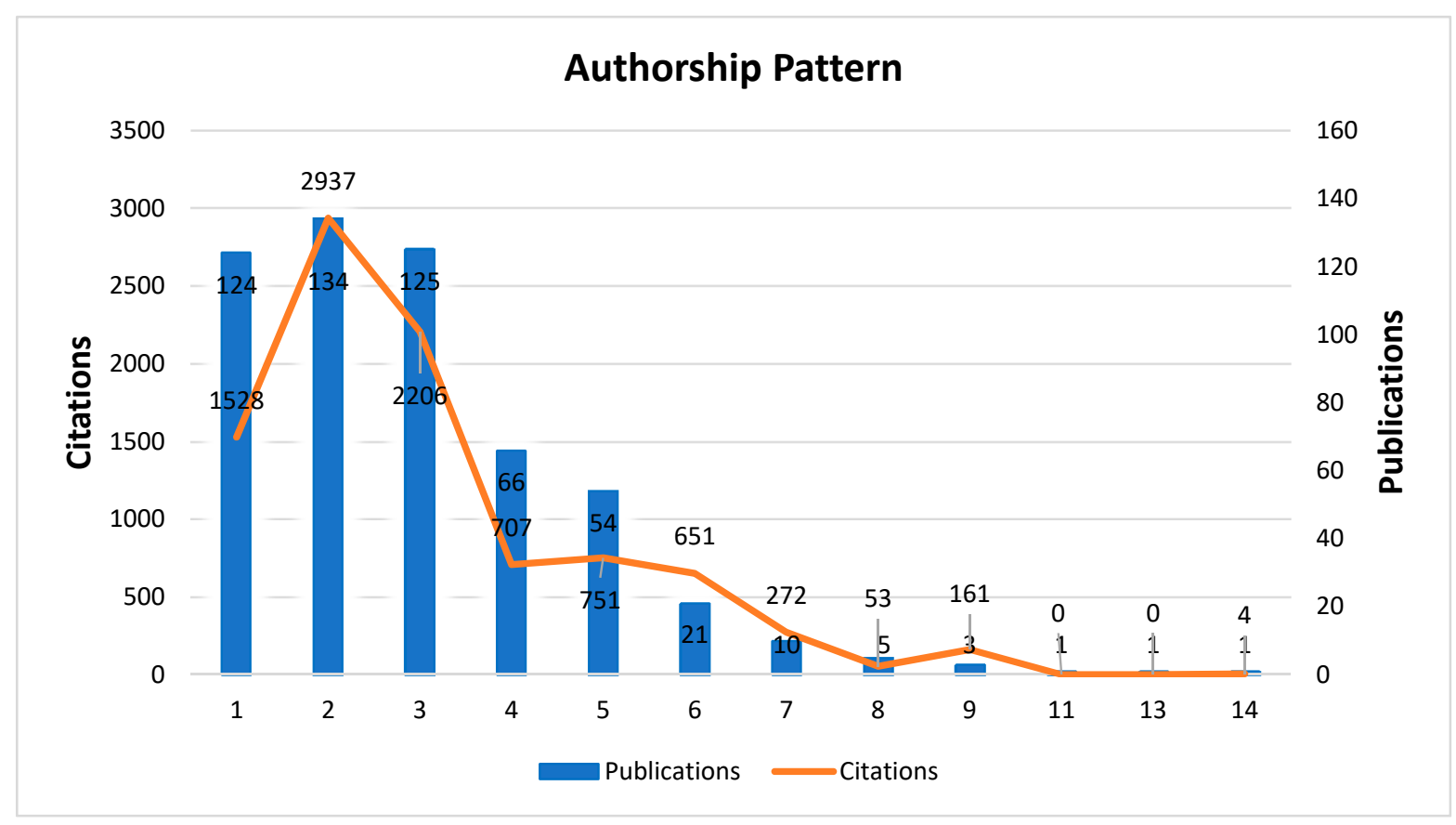

Figure 3. Authorship pattern of social support in education publications. 


\subsection{Keyword Co-Occurrences in Social Support}

Figure 4 presents the keyword co-occurrences in social support in education research. Keywords with minimum 5 times co-occurrences or more were included; 31 of 1333 keywords met the criterion. It shows that top five keywords are social support, higher education, education, international students, and stress with 98, 47, 26, 17, and 15 weightages of occurrences, respectively. Keywords (self-concept, youth, retention, support, doctoral education, inclusive education, and transition) show minimum co-occurrences (5) in this group.

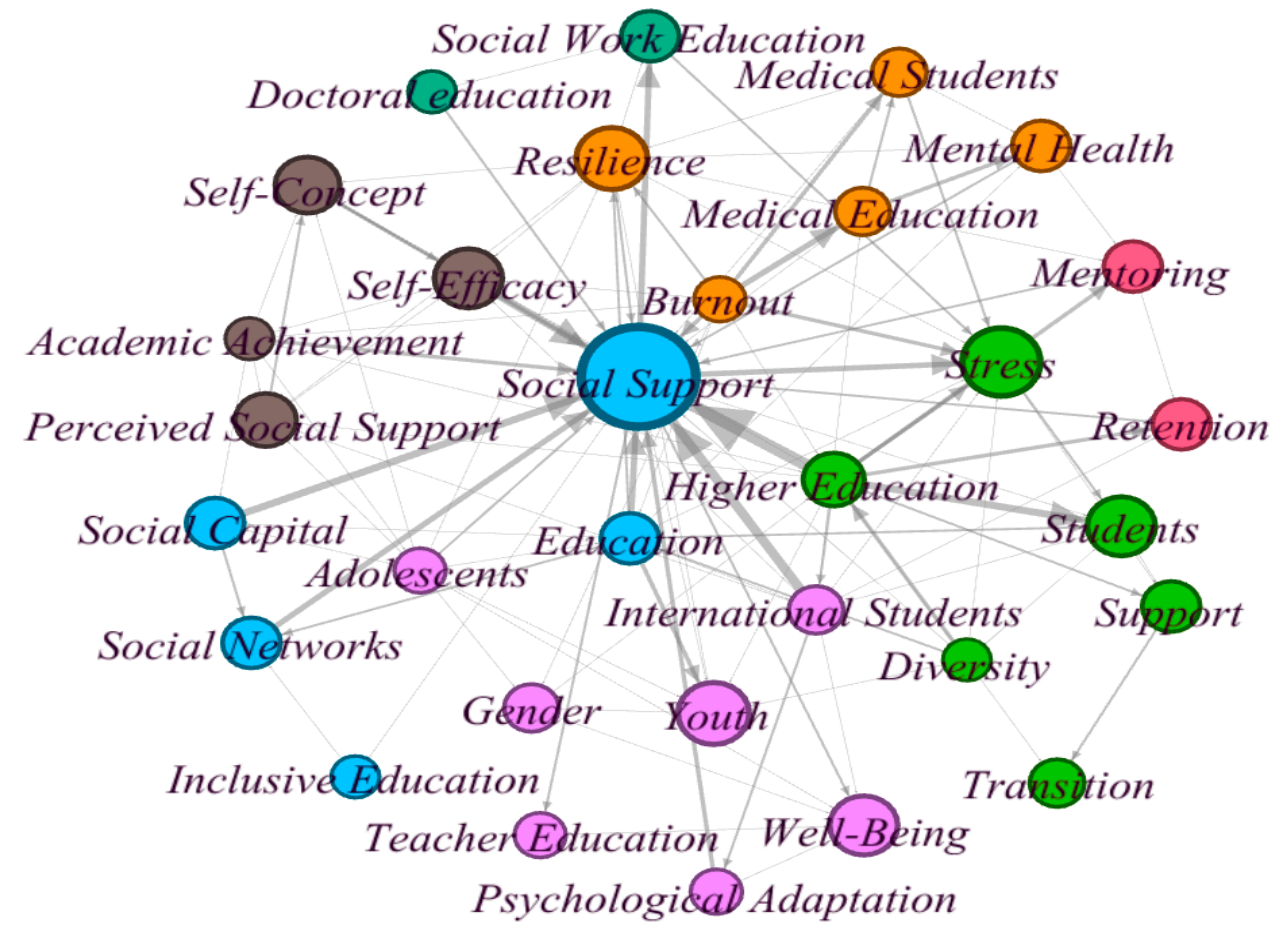

Figure 4. Keywords co-occurrences with minimum co-occurrences of 5 times; 31 meet the TH.

Closely related keywords are classified into seven clusters; the connections between the clusters can be described using quantitative network indicators. Social support (key word with highest occurrences) is placed in cluster 3 along with education, social capital, social networks and inclusive education. Social support, higher education, education, stress, and burnout are the keywords with 74, 36, 21, 21, and 20 total link strengths, respectively.

\subsection{Major Themes in Social Support in Education}

Table 5 lists the twenty themes in social support in education. Total publications classified under 20 themes are 351 and these publications were cited 5152 times. Social support is the top theme with 97 publications and 921 citations with 9.49 average citations per publication $(\mathrm{C} / \mathrm{P})$, followed by higher education (47 publications and 362 citations with 7.7 C/publications). Major temporal evolution of these two themes can be seen in the time period P3 (2011-2021) with 75 and 42 publications, respectively. Education is the theme which received 966 citations, the highest one in this table, for 31 publications, whereas the medical theme has 68.27 average citations per publication $(C / P)$ for 11 publications and 751 citations. The major five themes of the selected time periods are under:

P1 (1977-2000) Social Support (4), Medical (4), Education (3), Stress (3) and Undergraduate (3)

P2 (2001-2010) Social Support (18), Education (8), Stress (7), Medical (5), and Higher Education (5)

P3 (2011-2021) Social Support (75), Higher Education (42), Education (20), International Students (16), and Resilience (13) 
Table 5. Main themes included in social support in education publications between 1977 and 2020 .

\begin{tabular}{|c|c|c|c|c|c|c|c|}
\hline \multirow{2}{*}{ SR. } & \multirow{2}{*}{ Themes } & \multirow{2}{*}{$\mathbf{T P}$} & \multirow{2}{*}{ TC } & \multirow{2}{*}{$\mathrm{C} / \mathrm{P}$} & P1 & P2 & P3 \\
\hline & & & & & 1977-2000 & 2001-2010 & 2011-2021 \\
\hline 1. & Social Support & 97 & 921 & 9.49 & 4 & 18 & 75 \\
\hline 2. & Higher Education & 47 & 362 & 7.70 & 0 & 5 & 42 \\
\hline 3. & Education & 31 & 966 & 31.16 & 3 & 8 & 20 \\
\hline 4. & Stress & 20 & 363 & 18.15 & 3 & 7 & 10 \\
\hline 5. & International Students & 17 & 155 & 9.12 & 0 & 1 & 16 \\
\hline 6. & Burnout & 14 & 217 & 15.50 & 1 & 2 & 11 \\
\hline 7. & Resilience & 13 & 155 & 11.92 & 0 & 0 & 13 \\
\hline 8. & Students & 13 & 188 & 14.46 & 2 & 2 & 9 \\
\hline 9. & Medical & 11 & 751 & 68.27 & 4 & 5 & 2 \\
\hline 10. & Medical Education & 11 & 89 & 8.09 & 0 & 0 & 11 \\
\hline 11. & Mental Health & 9 & 177 & 19.67 & 0 & 2 & 7 \\
\hline 12. & Self-Efficacy & 9 & 168 & 18.67 & 0 & 1 & 8 \\
\hline 13. & Social Capital & 8 & 93 & 11.63 & 0 & 2 & 6 \\
\hline 14. & Social Networks & 8 & 83 & 10.38 & 0 & 3 & 5 \\
\hline 15. & Teacher Education & 8 & 95 & 11.88 & 0 & 0 & 8 \\
\hline 16. & Perceived Social Support & 7 & 67 & 9.57 & 0 & 0 & 7 \\
\hline 17. & Medical Students & 7 & 84 & 12.00 & 0 & 1 & 6 \\
\hline 18. & Gender & 7 & 70 & 10.00 & 0 & 0 & 7 \\
\hline 19. & Social Work Education & 7 & 83 & 11.86 & 0 & 3 & 4 \\
\hline 20. & Undergraduate & 7 & 65 & 9.29 & 3 & 1 & 3 \\
\hline
\end{tabular}

This table lists the main themes included in social support in education. It also shows the total number of publications classified under the respective theme (TP), total citations associated with these publications (TC), and average citations per publication $(\mathrm{C} / \mathrm{P})$. The remaining three columns ( $\mathrm{P} 1, \mathrm{P} 2$, and $\mathrm{P} 3$ ) depict the temporal evolution of the themes over three periods (1977-2000, 2001-2010, 2011-2021, respectively) and presents the respective count of the publications for each period.

\subsection{Bibliographic Coupling of Countries}

Figure 5 presents the bibliographic coupling of countries in social support in education research. Countries with a minimum 5 documents or more were included; 28 of 73 countries meet the criterion. Countries with the highest bibliographic coupling activity included the United States (194 documents, 3392 citations, and 3629 total link strength); the United Kingdom (56 documents, 1377 citations, and 1820 total link strength); and Australia (50 documents, 581 citations, and 1766 total link strength). Countries are grouped into clusters for their close relations in content; clusters' connections are described using quantitative network indicators. Bibliographic couplings of counties in social support in education research were classified into seven clusters. The United States, the country with the highest research production in social support in education research with total publications of 194 (citations 3392) [Table 2], is in the cluster 3 along with Turkey, Malaysia, Norway, and Thailand. The United Kingdom (publications 56, and citations 1377, Table 2) is with Finland and Sweden in the cluster 6. The Russian Federation is placed in cluster 7.

\subsection{Bibliographic Coupling of Journals}

Bibliographic coupling is a measure of subject matter commonality among different publications, and journals are bibliographically coupled if they refer to a common third publication. Figure 6 illustrates the bibliographic coupling among selected journals. The size of the circle and its colors indicate bibliographic coupling levels and different coupling clusters, respectively. Journals with a minimum of three or more publications were included; 25 of 259 journals met this criterion. Journals with the highest bibliographic coupling activity included Academic Medicine (30 documents, 1235 citations, and a 214 total link strength); the BMC Medical Education (30 documents, 565 citations, and a 490 total link 
strength); and Medical Teacher ( 30 documents, 663 citations, and a 234 total link strength). Journals that are closely related in content are classified into clusters; the connections between the clusters can be described using quantitative network indicators. Bibliographic couplings of journals in social support in education research were classified into four clusters and visually displayed using the gephi package.

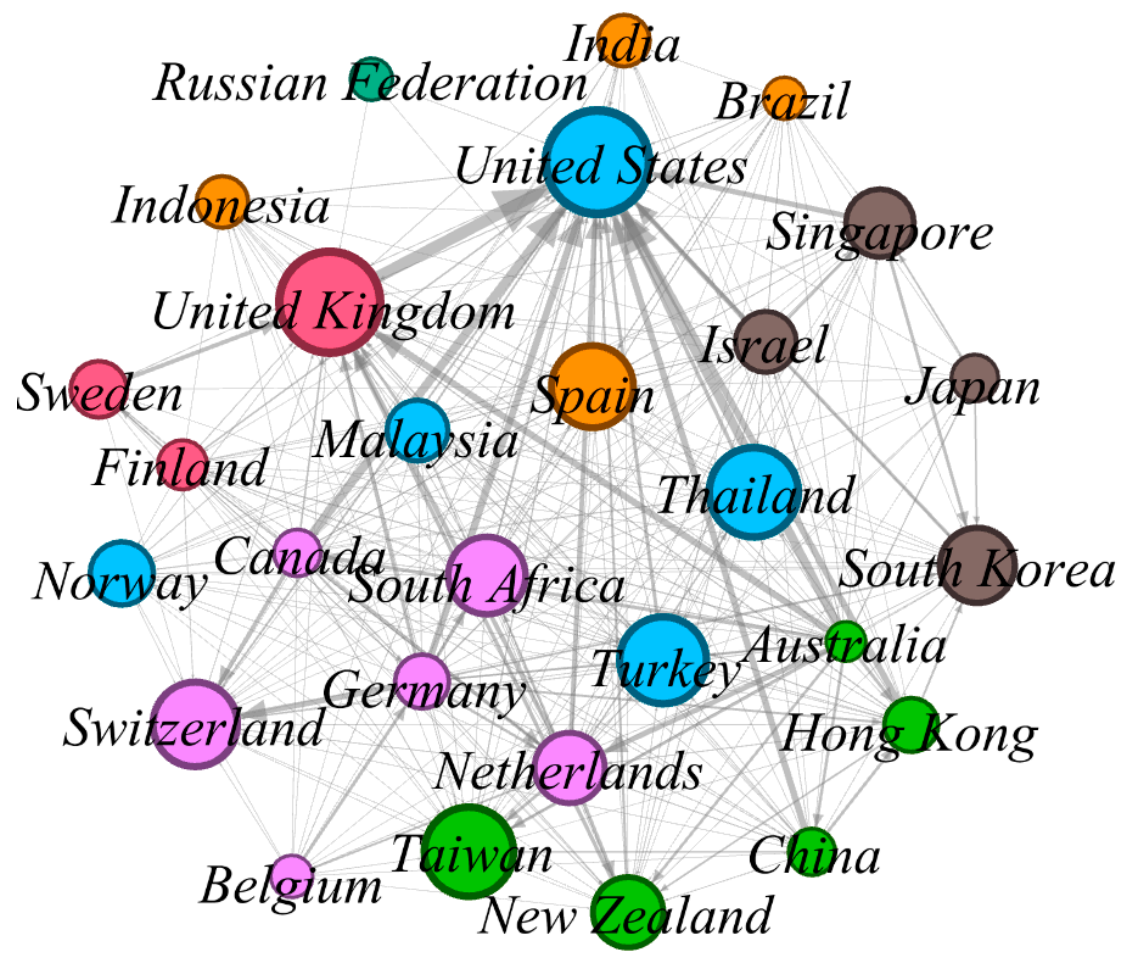

Figure 5. Bibliographic coupling of countries that published a minimum of 5 documents out of 73 countries; 28 meet the TH.

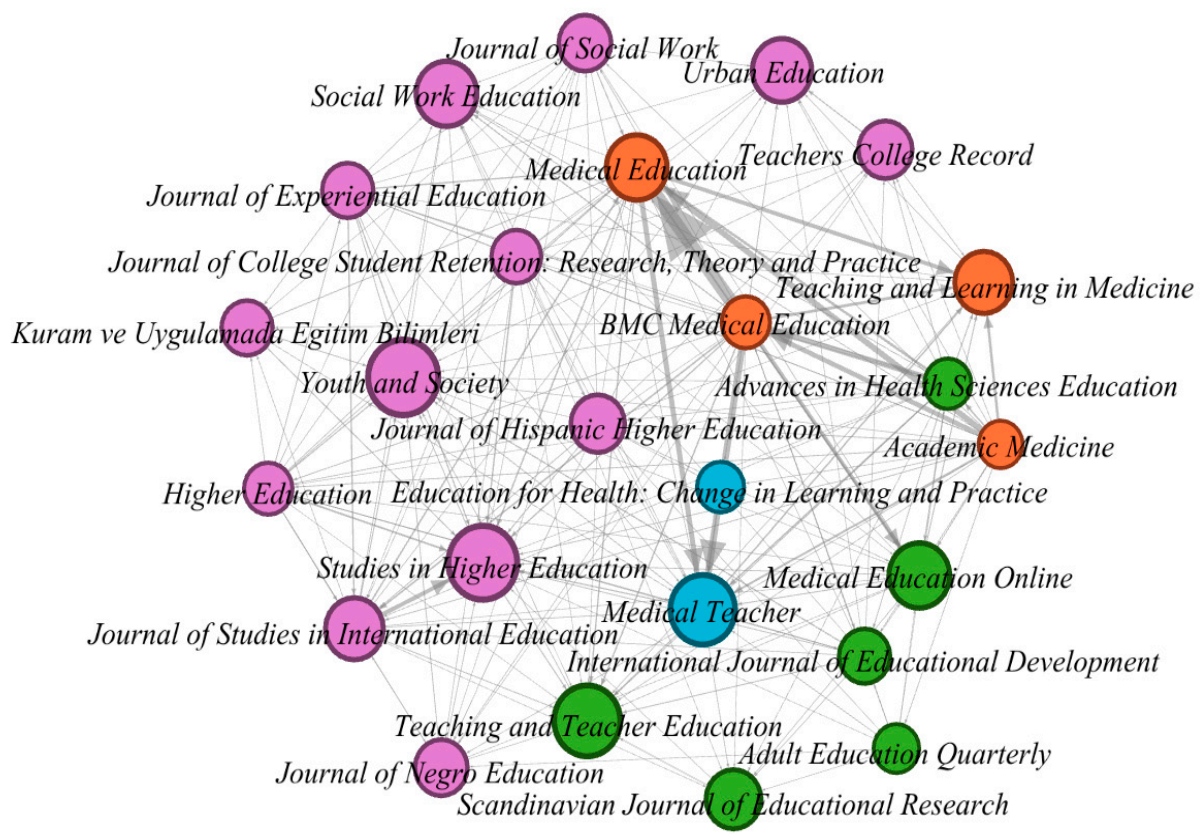

Figure 6. Bibliographic coupling of journals: total 259 journals, minimum no. of docs $=3$, citations $=$ 30 and 25 meet $\mathrm{TH}$. 


\subsection{Bibliographic Coupling of Authors}

Figure 7 presents the bibliographic coupling of authors in social support in education research. Authors with a minimum 2 documents and having 20 citations were included; 30 of 1602 authors meet the criterion. Authors with the highest bibliographic coupling activity included Pyhältö, K. (University of Oulu, Finland) (5 publications, 74 citations, and 649 total link strength); Bodycott P. (3 documents, 23 citations, and 201 total link strength); Gijbels D. (3 documents, 43 citations, and 243 total link strength); Mak A.S. (3 documents, 23 citations, and 201 total link strength); and Pietarinen J. (3 documents, 53 citations, and 606 total link strength).

Authors are classified under nine different clusters. Details of these clusters are as under:

1 (7 authors), 2 (5 authors), 3 (5 authors), 4 (4 authors), 5 ( 3 authors), 6 ( 2 authors), 7 ( 2 authors), 8 ( 1 authors), and 9 ( 1 authors).

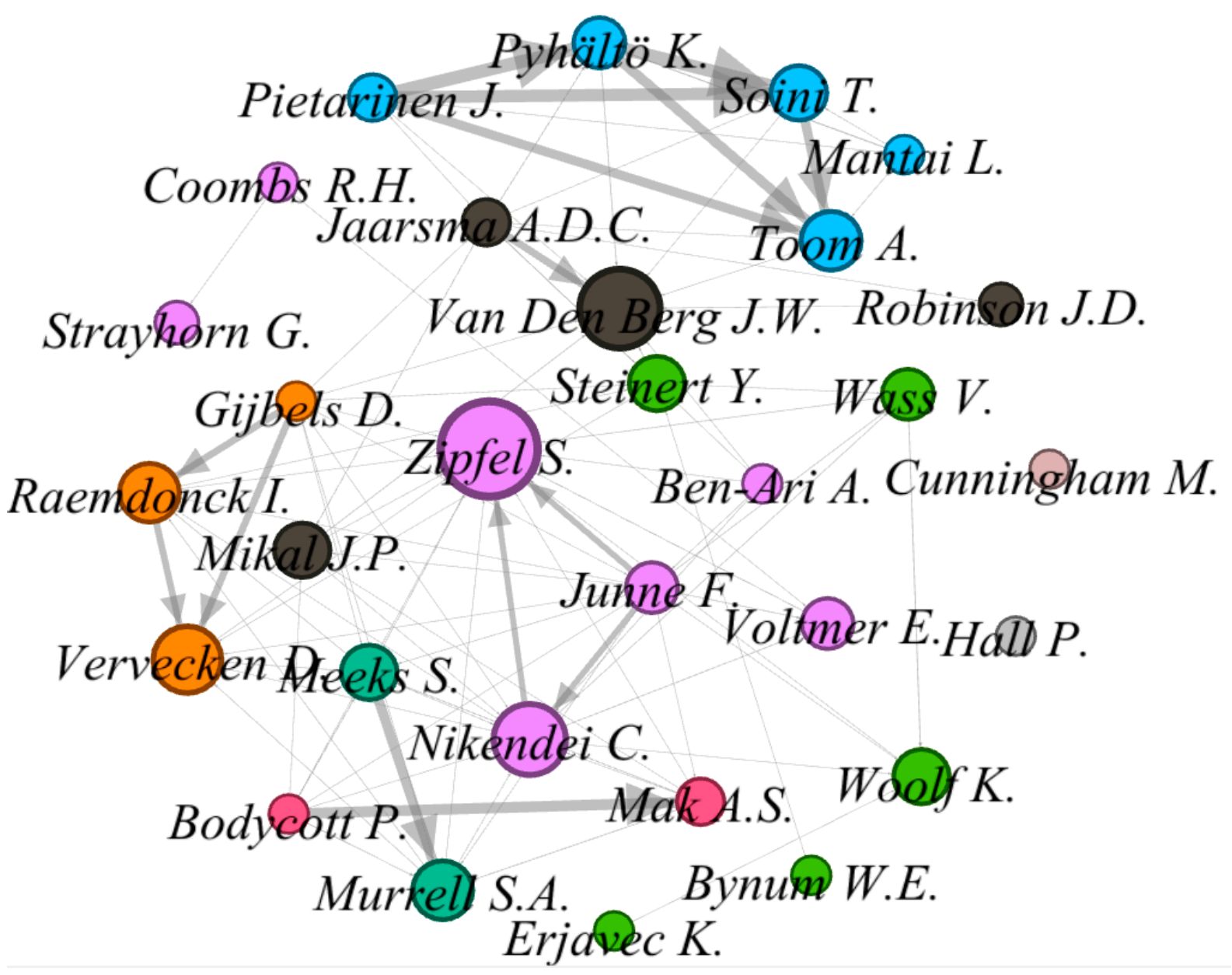

Figure 7. Bibliographic coupling of authors with a minimum 2 documents of an author having 20 citations each; 30 meet the TH.

\subsection{Co-Citation Network of Authors}

Figure 8 presents the co-citation network of authors in social support in education research. Authors with 30 or more citations are included; 24 of 1602 total authors meet the criterion. It shows that the top five authors are Dyrbye, LN, Bandura, A, Cohen, S, Shanafelt, TD, and Bakker, AB with weightage (citations) of 82, 78, 73, 67, and 61, respectively. Authors are grouped into clusters and connections between the clusters can be seen through quantitative network indicators. There are 5 total cluster of authors; 1 (11 authors), 2 (4 authors), 3 (4 authors), 4 ( 3 authors), and 5 ( 2 authors). 


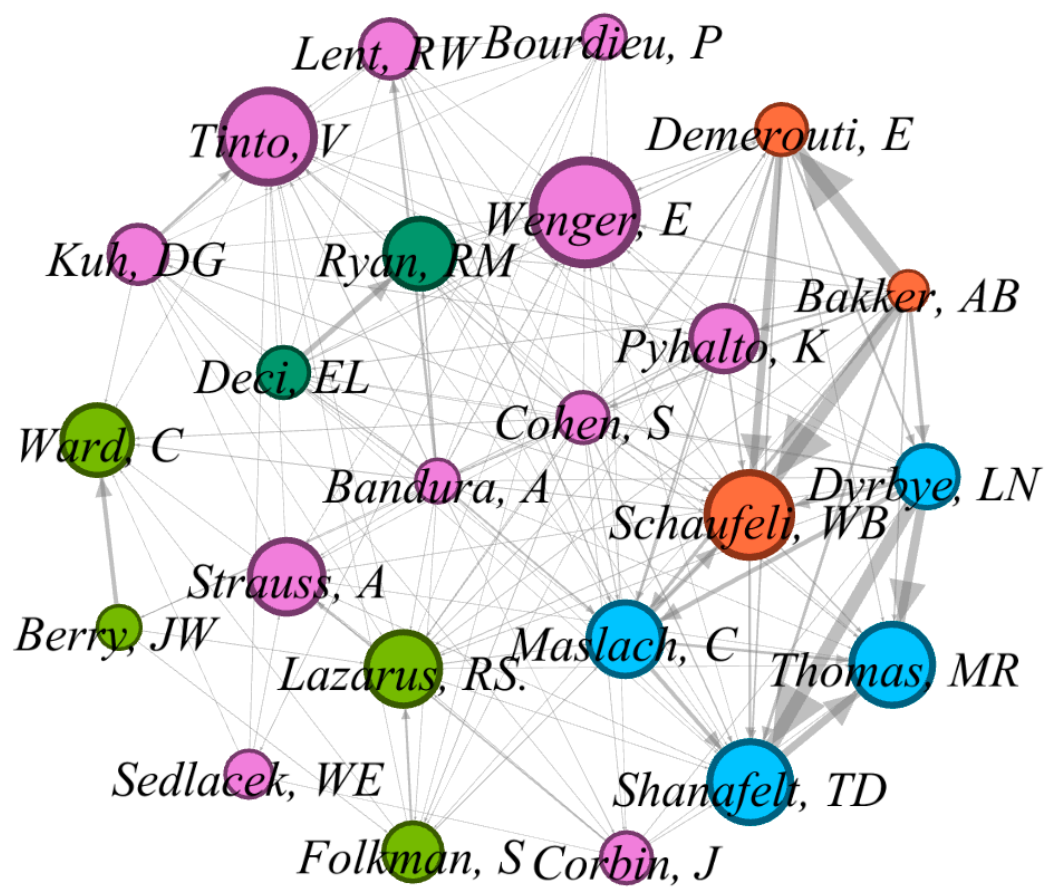

Figure 8. Co-citation network of authors with minimum citations $=30$ times; 24 meet the TH.

\subsection{Three-Factor Analysis (Countries, Keywords, and Journals)}

Figure 9 presents the three-factor analysis of the relationship among countries, keywords, and journals. It shows that the top five countries (USA, United Kingdom, Germany, Canada, and Australia) published social support in education literature mostly using four main keywords (social support, education, higher education and stress). These countries and keywords have a strong relationship with five journals (Academic Medicine, Advances in Health Sciences Education, BMC Medical Education, Medical Teacher, and Medical Education). The leading positions of developed countries in medical sciences and medical journals being highly influential in this area [47] make these countries as main sources of publications and publishing institutions.

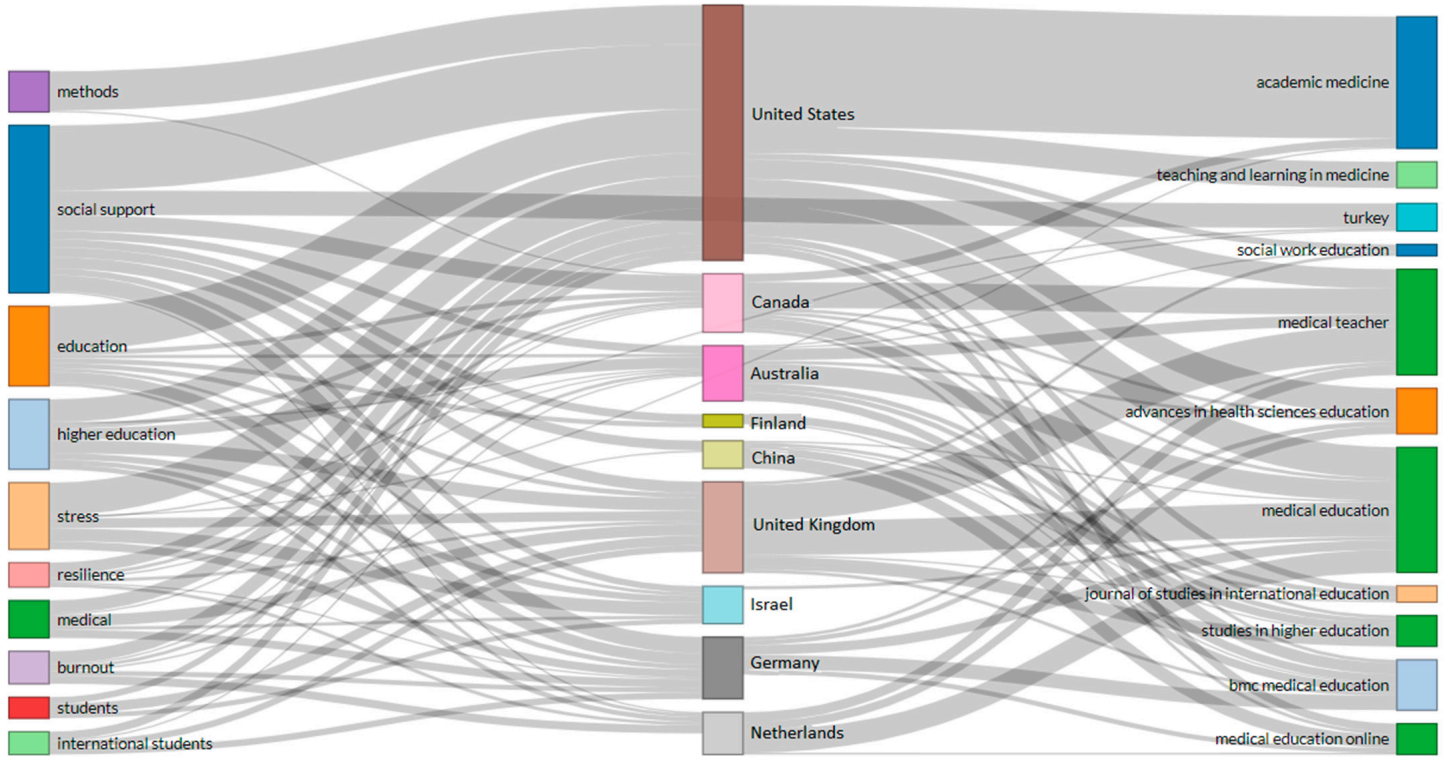

Figure 9. Three-factor analysis of the relationship among keywords (left), countries (middle), and journals (right). 
Figure 10 demonstrates evolution of keywords in three different stages (1983-2005, 2006-2015, and 2016-2020). Keywords "social support and education" are important keywords as these show up in all three stages, however "stress" has only shown up in the first two stages. It is noticed that most of the research in this stage relates to medical students, gender and stress. This is supported by the high level of stress among medical students during those years [49,50]. Figure 10 shows that stage one (1983-2005) has little connection with stage two (2006-2015), as there are only two common keywords between these two stages; in addition, stage two (2006-2015), and stage three (2016-2020) have more common keywords as compared to the previous stage, which manifests that the focuses of these two stages are relatively close.

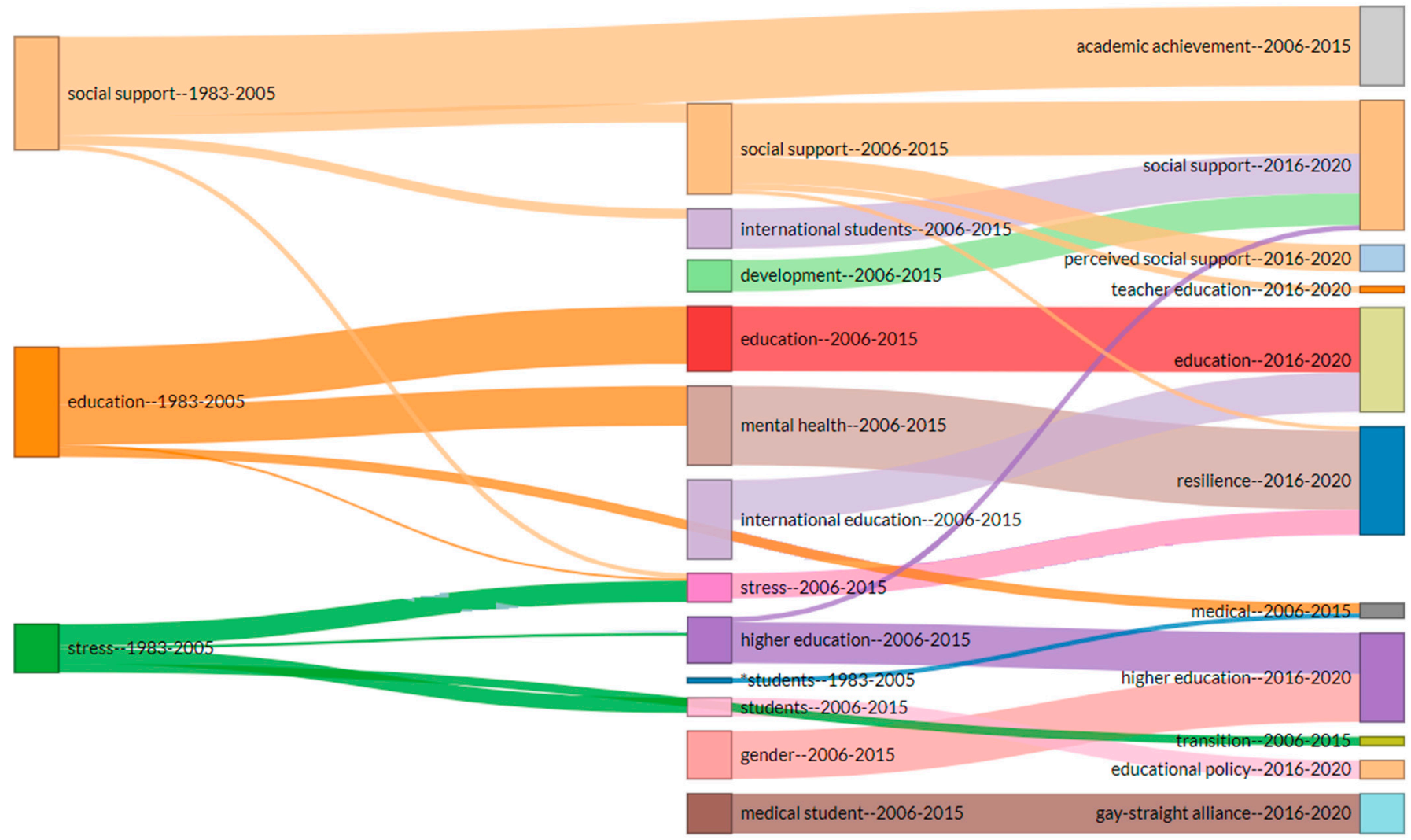

Figure 10. Thematic evolution map of keywords from 1977 to 2020 with respect to social support in education research. Usage and emergence of keywords related to this study is highlighted.

\section{Conclusions}

Overall findings reveal that although social support research progressed slowly, it started gaining importance with the passage of time and has become a mainstream area in the field of education. This is evident by the number of publications and upsurge in number of citations. Social support was studied and practiced in the medical fields mainly for patients and at the community levels for families. The importance of social support to health care professionals in COVID-19 pandemic still form a major part of COVID-19 related research [51-53]. Similarly, during the pandemic, research on social support to patients and people suffering due to pandemic related mental health problems was also a main research agenda in 2020 [54-56]. No doubt, the main reason behind the importance of social support in education is the diversity of students enrolling in universities requiring social support at the institutional level. Social support will become even more crucial in this pandemic that the world is going through. As found, social support along with administrative, course design and technical support has a positive 
impact on the quality of e-learning in higher education during the COVID-19 pandemic [57]. Being the first bibliometric study in the field of social support in education, the present study will help the researchers to identify the previous research trends and research gaps, and implications of research. It will also help the educational policy makers, educationists and educational administrators to make informed decisions in the current scenario of the COVID-19 pandemic. A limitation of the study is its reliance on a single database source (Scopus) and its selection of broader keywords "education AND social support". This study is also limited to purely correlational and quantitative nature and hence the results of the study may be strengthened with qualitative inspection of materials. Future research may explore and evaluate the importance of social support in the context of the specific education level, for example, higher education or primary level.

Author Contributions: Conceptualization, S.R. and A.K.; methodology, M.A. and S.U.R.; software, M.A. and S.U.R.; validation, M.A. and S.U.R.; formal analysis, M.A. and S.U.R.; investigation, S.R.; resources, S.U.R.; data curation, M.A. and S.U.R.; writing-original draft preparation, S.R. and A.K.; writing-review and editing, S.R. and A.K.; visualization, S.U.R. and M.A.; supervision, S.R.; project administration, S.U.R.; funding acquisition, A.K. All authors have read and agreed to the published version of the manuscript.

Funding: This research received no external funding.

Institutional Review Board Statement: Not Applicable.

Informed Consent Statement: Not Applicable.

Acknowledgments: The authors would like to acknowledge the support of Prince Sultan University for paying the Article Processing Charges (APC) of this publication.

Conflicts of Interest: The authors declare no conflict of interest.

\section{References}

1. Awang, M.M.; Kutty, F.M.; Ahmad, A.R. Perceived Social Support and Well Being: First-Year Student Experience in University. Int. Educ. Stud. 2014, 7, 261-270. [CrossRef]

2. Tayfur, C.; Ulupinar, S. The Effect of Perceived Social Support on the Academic Achievement of Health College Students. J. Psychiatr. Nurs./Psikiyatr. Hemsireleri Dern. 2016, 7, 1-6. [CrossRef]

3. Malecki, C.K.; Demary, M.K. Measuring perceived social support: Development of the child and adolescent social support scale (CASSS). Psychol. Sch. 2002, 39, 1-18. [CrossRef]

4. Thoits, P.A. Life stress, social support, and psychological vulnerability: Epidemiological considerations. J. Community Psychol. 1982, 10, 341-362. [CrossRef]

5. Adams, B.N. Interaction Theory and the Social Network. Sociometry 1967, 30, 64-78. [CrossRef]

6. Cobb, S. Social support as a moderator of life stress. Psychosom. Med. 1976, 38, 300-314. [CrossRef]

7. Cutrona, C.E.; Russell, D.W. Type of social support and specific stress: Toward a theory of optimal matching. In Social Support: An Interactional View; Wiley series on personality processes; John Wiley \& Sons: Oxford, UK, 1990; pp. 319-366.

8. Uchino, B.N. Social Support and Physical Health: Understanding the Health Consequences of Relationships; Yale University Press: New Haven, CT, USA, 2004.

9. Wills, T.A. Social support and interpersonal relationships. In Prosocial Behavior; Review of personality and social psychology; Sage Publications, Inc.: Thousand Oaks, CA, USA, 1991; Volume 12, pp. 265-289.

10. House, J.S.; Kahn, R.L.; McLeod, J.D.; Williams, D. Measures and concepts of social support. In Social Support and Health; Academic Press: San Diego, CA, USA, 1985; pp. 83-108.

11. Langford, C.P.H.; Bowsher, J.; Maloney, J.P.; Lillis, P.P. Social support: A conceptual analysis. J. Adv. Nurs. 1997, 25, 95-100. [CrossRef]

12. Demir, M.; Leyendecker, B. School-Related Social Support Is Associated With School Engagement, Self-Competence and HealthRelated Quality of Life (HRQoL) in Turkish Immigrant Students. Front. Educ. 2018, 3. [CrossRef]

13. Tian, L.; Tian, Q.; Huebner, E.S. School-Related Social Support and Adolescents' School-Related Subjective Well-Being: The Mediating Role of Basic Psychological Needs Satisfaction at School. Soc. Indic. Res. 2016, 128, 105-129. [CrossRef]

14. Vedder, P.; Boekaerts, M.; Seegers, G. Perceived social support and well being in school; The role of students' ethnicity. J. Youth Adolesc. 2005, 34, 269-278. [CrossRef]

15. Saylor, C.F.; Leach, J.B. Perceived bullying and social support in students accessing special inclusion programming. J. Dev. Phys. Disabil. 2009, 21, 69-80. [CrossRef]

16. Fisher, S. Stress in Academic Life: The Mental Assembly Line; Open University Press: Maidenhead, UK, $1994 ;$ pp. xiii, 106. 
17. Tinto, V. Reconstructing the First Year of College. Plan. High. Educ. 1996, 25, 1-6.

18. Marhamah, F; Hamzah, H. The relationship between social support and academic stress among first year students at Syiah Kuala university. Psikoislamedia J. Psikol. 2017, 1, 149-171. [CrossRef]

19. Hillman, K. The First Year Experience: The Transition from Secondary School to University and TAFE in Australia; 2005; p. 44. Available online: https:/ / research.acer.edu.au/lsay_research/44 (accessed on 11 December 2020).

20. Liu, W.; Mei, J.; Tian, L.; Huebner, E.S. Age and gender differences in the relation between school-related social support and subjective well-being in school among students. Soc. Indic. Res. 2016, 125, 1065-1083. [CrossRef]

21. Wentzel, K.R.; Muenks, K.; McNeish, D.; Russell, S. Peer and teacher supports in relation to motivation and effort: A multi-level study. Contemp. Educ. Psychol. 2017, 49, 32-45. [CrossRef]

22. Berndt, T.J. Friends' influence on students' adjustment to school. Educ. Psychol. 1999, 34, 15-28. [CrossRef]

23. Wentzel, K.R. Social relationships and motivation in middle school: The role of parents, teachers, and peers. J. Educ. Psychol. 1998, 90, 202-209. [CrossRef]

24. Driessen, G.; Withagen, V. Language Varieties and Educational Achievement of Indigenous Primary School Pupils. Lang. Cult. Curric. 1999, 12, 1-22. [CrossRef]

25. Nickerson, A.B.; Nagle, R.J. Parent and peer attachment in late childhood and early adolescence. J. Early Adolesc. 2005, 25, 223-249. [CrossRef]

26. Malecki, C.K.; Demaray, M.K. What Type of Support Do They Need? Investigating Student Adjustment as Related to Emotional, Informational, Appraisal, and Instrumental Support. Sch. Psychol. Q. 2003, 18, 231-252. [CrossRef]

27. Bokhorst, C.L.; Sumter, S.R.; Westenberg, P.M. Social Support from Parents, Friends, Classmates, and Teachers in Children and Adolescents Aged 9 to 18 Years: Who Is Perceived as Most Supportive? Soc. Dev. 2010, 19, 417-426. [CrossRef]

28. Malecki, C.K.; Demaray, M.K. Social support as a buffer in the relationship between socioeconomic status and academic performance. Sch. Psychol. Q. 2006, 21, 375-395. [CrossRef]

29. Rueger, S.Y.; Malecki, C.K.; Demaray, M.K. Gender differences in the relationship between perceived social support and student adjustment during early adolescence. Sch. Psychol. Q. 2008, 23, 496-514. [CrossRef]

30. Goebert, D. Social support, mental health, minorities, and acculturative stress. In Determinants of Minority Mental Health and Wellness; Loue, S., Sajatovic, M., Eds.; Springer: New York, NY, USA, 2009; pp. 125-148.

31. Garcia-Reid, P.; Reid, R.J.; Peterson, N.A. School engagement among Latino youth in an urban middle school context:Valuing the role of social support. Educ. Urban Soc. 2005, 37, 257-275. [CrossRef]

32. Shi, Y.; Sun, F.; Liu, Y.; Marsiglia, F.F. Perceived threat of Alzheimer's disease and related dementias among older Chinese Americans in subsidized housing: Through a cultural lens. Dementia 2020, 19, 1777-1793. [CrossRef] [PubMed]

33. Lee, K.; Lawton, C.; Boateng, A. Parental experiences for teenage mothers living in poverty: Associations of head start. Affilia 2020, 0886109920963032. [CrossRef]

34. Nakagawa, T.; Hülür, G. Social Integration and Terminal Decline in Life Satisfaction Among Older Japanese. J. Gerontol. Ser. B 2019, 75, 2122-2131. [CrossRef]

35. Rouse, H.L.; Hurt, T.R.; Melby, J.N.; Bartel, M.; McCurdy, B.; McKnight, E.; Zhao, F.; Behrer, C.; Weems, C.F. Pregnancy and Parenting Among Youth Transitioning from Foster Care: A Mixed Methods Study. Child Youth Care Forum 2021, 50, $167-197$. [CrossRef]

36. Agyekum, B.; Siakwah, P.; Boateng, J.K. Immigration, education, sense of community and mental well-being: The case of visible minority immigrants in Canada. J. Urban. Int. Res. Placemaking Urban Sustain. 2020, 1-15. [CrossRef]

37. Macuka, I.; Tucak Junaković, I.; Božić, D. Burnout among Palliative Care Professionals. Društvena Istraživanja Časopis Za Opća Društvena Pitanja 2020, 29, 287-308. [CrossRef]

38. Abt, H.A. Institutional productivities. PASP 1993, 105, 794-798. [CrossRef]

39. Siddique, N.; Rehman, S.U.; Khan, M.A.; Altaf, A. Library and information science research in Pakistan: A bibliometric analysis, 1957-2018. J. Librariansh. Inf. Sci. 2020, 53, 89-102. [CrossRef]

40. Tijjani, B.; Ashiq, M.; Siddique, N.; Khan, M.A.; Rasul, A. A bibliometric analysis of quality research papers in Islamic finance: Evidence from Web of Science. ISRA Int. J. Islamic Financ. 2020. ahead-of-print. [CrossRef]

41. Ahmad, S.; Ur Rehman, S.; Ashiq, M. A Bibliometric Review of Arab World Research from 1980-2020. Sci. Technol. Libr. 2021, 1-21. [CrossRef]

42. Gul, S.; Rehman, S.U.; Ashiq, M.; Khattak, A. Mapping the Scientific Literature on COVID-19 and Mental Health. Psychiatr. Danub. 2020, 32, 463-471. [CrossRef]

43. Jabali, K.A.; Ashiq, M.; Ahmad, S.; Rehman, S.U. A Bibliometric Analysis of Research Productivity on Diabetes Modeling and Artificial Pancreas 2001 to 2020. Libr. Philos. Pract. 2020,1-19. Available online: https://digitalcommons.unl.edu/libphilprac/43 05/ (accessed on 11 December 2020).

44. Baas, J.; Schotten, M.; Plume, A.; Côté, G.; Karimi, R. Scopus as a curated, high-quality bibliometric data source for academic research in quantitative science studies. Quant. Sci. Stud. 2020, 1, 377-386. [CrossRef]

45. Mishra, S. Social networks, social capital, social support and academic success in higher education: A systematic review with a special focus on 'underrepresented' students. Educ. Res. Rev. 2020, 29, 100307. [CrossRef]

46. Shu, F.; Ahmed, S.F.; Pickett, M.L.; Ayman, R.; McAbee, S.T. Social support perceptions, network characteristics, and international student adjustment. Int. J. Intercult. Relat. 2020, 74, 136-148. [CrossRef] 
47. Aparicio-Martinez, P.; Perea-Moreno, A.-J.; Martinez-Jimenez, M.P.; Redel-Macías, M.D.; Vaquero-Abellan, M.; Pagliari, C. A Bibliometric Analysis of the Health Field Regarding Social Networks and Young People. Int. J. Environ. Res. Public Health 2019, 16, 4024. [CrossRef]

48. Saleem, F.; Khattak, A.; Ur Rehman, S.; Ashiq, M. Bibliometric Analysis of Green Marketing Research from 1977 to 2020. Publications 2021, 9, 1. [CrossRef]

49. Muirhead, V.; Locker, D. Canadian dental students' perceptions of stress and social support. Eur. J. Dent. Educ. 2008, 12, 144-148. [CrossRef] [PubMed]

50. Park, K.H.; Kim, D.; Kim, S.K.; Yi, Y.H.; Jeong, J.H.; Chae, J.; Hwang, J.; Roh, H. The relationships between empathy, stress and social support among medical students. Int. J. Med. Educ. 2015, 6, 103-108. [CrossRef] [PubMed]

51. Labrague, L.J.; De los Santos, J.A.A. COVID-19 anxiety among front-line nurses: Predictive role of organisational support, personal resilience and social support. J. Nurs. Manag. 2020, 28, 1653-1661. [CrossRef] [PubMed]

52. Raza, A.; Matloob, S.; Abdul Rahim, N.F.; Abdul Halim, H.; Khattak, A.; Ahmed, N.H.; Nayab, D.-e.; Hakeem, A.; Zubair, M. Factors Impeding Health-Care Professionals to Effectively Treat Coronavirus Disease 2019 Patients in Pakistan: A Qualitative Investigation. Front. Psychol. 2020, 11. [CrossRef]

53. Xiao, H.; Zhang, Y.; Kong, D.; Li, S.; Yang, N. The Effects of Social Support on Sleep Quality of Medical Staff Treating Patients with Coronavirus Disease 2019 (COVID-19) in January and February 2020 in China. Med. Sci. Monit. 2020, 26, e923549. [CrossRef] [PubMed]

54. Grey, I.; Arora, T.; Thomas, J.; Saneh, A.; Tohme, P.; Abi-Habib, R. The role of perceived social support on depression and sleep during the COVID-19 pandemic. Psychiatry Res. 2020, 293, 113452. [CrossRef] [PubMed]

55. Skalski, S.; Uram, P.; Dobrakowski, P.; Kwiatkowska, A. The link between ego-resiliency, social support, SARS-CoV-2 anxiety and trauma effects. Polish adaptation of the Coronavirus Anxiety Scale. Pers. Individ. Dif. 2021, 171, 110540. [CrossRef]

56. Yu, H.; Li, M.; Li, Z.; Xiang, W.; Yuan, Y.; Liu, Y.; Li, Z.; Xiong, Z. Coping style, social support and psychological distress in the general Chinese population in the early stages of the COVID-19 epidemic. BMC Psychiatry 2020, 20, 426. [CrossRef]

57. Sankar, J.; Kalaichelvi, R.; John, J.; Menon, N.; Elumalai, K.; Alqahtani, M.; Abumelha, M. Factors Affecting the Quality of E-Learning During the COVID-19 Pandemic from the Perspective of Higher Education Students. J. Inf. Technol. Educ. Res. 2020, $19,731-753$. 